\section{DNA Fingerprinting to Identify Nine Anthurium Pot Plant Cultivars and Examine Their Genetic Relationship}

\author{
D.G. Ranamukhaarachchi ${ }^{1}$ \\ Department of Environmental Horticulture, Institute of Food and Agricultural \\ Sciences, University of Florida, Gainesville, FL 32611 \\ R.J. Henny $\mathbf{2}^{2}$ \\ Mid-Florida Research and Education Center, 2725 Binion Road, Apopka, \\ FL 32703
}

C.L. Guy and Q.B. Li

Department of Environmental Horticulture, Institute of Food and Agricultural Sciences, University of Florida, Gainesville, FL 32611

Additional index words. Anthurium, Araceae, cultivar identification, molecular markers, RAPD, plant breeding

Abstract. Randomly amplified polymorphic DNA (RAPD) markers were utilized to determine the genetic relationships of nine morphologically similar pot plant cultivars of Anthurium sp. by developing DNA fingerprints (DFP). Of 25 arbitrary primers screened, nine generated DFPs that were used in computing the genetic distance (d) and similarity coefficient $(C)$ values. All cultivars tested exhibited a high degree of genetic similarity. 'Lady Ann' and 'Lady Beth' possessed the closest relationship with $d$ and $C$ values of 0.06 and 0.98 , respectively. The next closest genetic relationship was between 'Red Hot' and 'Southern Blush' $(\mathrm{d}=\mathbf{0 . 3 3}, \mathrm{C}=\mathbf{0 . 8 9})$. These two cultivars exhibited a more distant relationship to the other seven cultivars as indicated by higher ' $d$ ' values. However, this study showed that the nine Anthurium cultivars examined were genetically closely related. These cultivars share specific DNA bands with three possible parental species (A. andraeanum Linden ex Andre, $A$. antioquens L., and $A$. amnicola Dressler) included in this study, which may indicate similarities in their pedigree. This study shows that RAPDs can be a useful tool to distinguish Anthurium pot plant cultivars as well as identify their genetic relationships.

Most Anthurium breeding programs for developing pot plant-type cultivars utilize $A$. antioquence and $A$. amnicola as parents because both species are dwarf and highly floriferous (Kamemoto, 1981; Kamemoto and Sheffer, 1978). These species are often crossed with $A$. andraeanum cut-flower cultivars in order to obtain hybrids with a wide color range. This crossing scheme has resulted in new cultivars with similar morphologies that can make identification and assurance of pedigree difficult. Kobayashi et al. (1987) reported the use of isozyme markers to differentiate cutflower-type A. andraeanum cultivars. The randomly amplified polymorphic DNA (RAPD) technique provides a useful tool for genetic characterization studies, and has several advantages, including low cost, quick turnover time, and no requirement for DNA sequencing or radioisotope use (Williams et

Received for publication 20 Mar. 2000. Accepted for publication 14 Sept. 2000. Florida Agricultural Experiment Station Journal Series R-07744. The cost of publishing this paper was defrayed in part by the payment of page charges. Under postal regulations, this paper therefore must be hereby marked advertisement solely to indicate this fact.

${ }^{1}$ Current address: Centers for Disease Control, 1600 Clifton Rd., NE, MSG18, Atlanta, GA 30333. E-mail address: dnr4@cdc.gov.

${ }^{2}$ To whom requests for reprints should be addressed. buffer containing $7 \mathrm{~m}$ urea, $0.35 \mathrm{M} \mathrm{NaCl}, 50$ mm Tris (pH 8.0), $20 \mathrm{~mm}$ EDTA and 1\% sarkosyl (N-lauryl sarcosine), followed by removal of proteins and polysaccharides using a 25 phenol : 24 chloroform : 1 isoamyl alcohol mixture. The RNA was removed by incubating with RNase $37{ }^{\circ} \mathrm{C}$ for $30 \mathrm{~min}$. The final DNA extract was dissolved in Tris-EDTA (TE) buffer. Yield and quality of DNA were tested using both spectrophotometry and gel electrophoresis.

DNA amplification and gel electrophoresis. Optimized polymerase chain reaction (PCR) (Mullis et al., 1986) amplification solutions contained $2.5 \mathrm{~mm} \mathrm{Mg} \mathrm{Mg}^{2+}, 200 \mu \mathrm{M}$ deoxyribonucleotide phosphates (dNTPs), 2.5 pmol primer (10-mer arbitrary primers; Operon Technologies, Alameda, Calif.), 0.3 units Taq DNA polymerase (Promega, Madison, Wis.), $1 \mu \mathrm{L}$ template DNA (15 ng), buffer consisting $50 \mathrm{~mm} \mathrm{KCl}, 10 \mathrm{~mm}$ Tris $\mathrm{HCl}$ $(\mathrm{pH} 9)$ and $1 \%$ Triton $\mathrm{X}-100^{\circledR}$, all in a final volume of $15 \mu \mathrm{L}$. PCR was performed in a thermocycler (Biometra, Tampa, Fla.). A negative control without template DNA was included in each set of reactions to avoid misinterpretation of data associated with DNA contamination. Twenty-five primers from Operon Technologies, series B, AJ, AK, and $\mathrm{L}$ were screened for reactions generating reproducible results with unambiguous banding patterns. The PCR reactions were repeated three times with selected primers and the products were run for $3 \mathrm{~h}$ at $70 \mathrm{~V}$ in $1.5 \%$ agarose gels containing TAE buffer (Sambrook et al., 1989). Gels were then stained with $0.024 \%$ ethidium bromide and photographed using Polaroid type 667 film (Polaroid Corp., Cambridge, Mass.).

Analysis of RAPD data. All readily distinguishable bands in each RAPD profile were counted. To aid in band resolution, photographs were scanned and resolutions improved using Photoshop (Adobe Systems, San Jose, Calif.). RAPD profiles were then visually screened to identify both monomorphic and polymorphic bands. The presence or absence of bands was assigned values of one or zero, respectively. Data for bands present in all three replicates were compared in order to test for any missing markers not amplified during any one replication.

Data were analysed by computing the coefficient of similarity [C value] ( $\mathrm{Nei}$ and $\mathrm{Li}$, 1979) and genetic distances [d value] (Sneath and Sokal, 1973). C is the probability that a band from one individual will also be found in another, whereas $d$ is the number of dissimilar bands scored for any two cultivars divided by the total number of bands scored for those two individuals. The value for $\mathrm{C}=2 \mathrm{Mxy} /(\mathrm{Mx}+\mathrm{My})$, where $\mathrm{Mxy}=$ total number of bands shared by cultivar $\mathrm{x}$ and cultivar $\mathrm{y}, \mathrm{Mx}+\mathrm{My}=$ total number of bands scored in both cultivars. The RAPDistance software program version 1.03 (Armstrong et al., 1994) was used to calculate $\mathrm{C}$ and the square root of $\mathrm{d}$ for the nine cultivars in all possible pairwise combinations. Use of square root values of $\mathrm{d}$ aids in analysis by overcoming the cluster formation of resulting d values (Armstrong et al., 1994). 


\section{Results and Discussion}

DNA fingerprint analysis. Twenty-five primers were screened for their ability to generate reproducible DNA profiles, of which nine were selected that generated a total of 104 reproducible amplified bands. Of these bands, 74 were polymorphic and therefore useful for cultivar identification (Table 1 ). The total number of bands produced with each primer varied from 8 to 16 . Depending on the primer, the percentage of polymorphic bands observed among cultivars ranged from $50 \%$ to $88 \%$, which included six cultivar-specific bands. Sizes of the amplified DNA fragments ranged from 0.5 to $3 \mathrm{~Kb}$ (Fig. 1).

The DNA fingerprint (DFP) patterns generated by different primers for each cultivar ranged from five to nine. Primers $\mathrm{B}_{20}$ and $\mathrm{AJ}_{2}$ produced the highest number of unique fingerprints. Among all cultivars, the maximum number of identical patterns was found between 'Lady Ann' and 'Lady Beth'; only three primers $\left(\mathrm{AK}_{4}\right.$, $\mathrm{AJ}_{2}$ and $\mathrm{B}_{20}$ ) out of nine produced different DFP patterns that enabled differentiation of these two cultivars. 'Lady Ann' and 'Lady Beth' exhibited a close genetic relationship, as indicated by the lowest $d$ value and highest $C$ value in comparison with the other cultivar pairs tested (Table 2). In contrast, neither 'Red Hot' nor 'Southern Blush' generated DFP patterns identical with that of any other cultivar for all the primers tested. All other cultivars produced at least one identical DFP pattern.

Genetic relationship among cultivars. Index values for coefficient of similarity and genetic distances were used to show genetic relationships among cultivars (Table 2 ). The $\mathrm{C}$ values among all the cultivars ranged from 0.68 to 0.98 , which indicates high genetic similarity. The $\mathrm{d}$ values ranged from 0.33 to 0.69 , except that for 'Lady Ann' and 'Lady Beth', where an extremely low value of 0.06 was observed. This result, coupled with a C value of 0.98, indicates that 'Lady Ann' and 'Lady Beth' are almost identical genetically (Fig. 1, Table 2). These two cultivars share Anthurium $\times$ cultorum and Anthurium antioquence as parents (Plant Patent Nos.- 8129 and 8131, 'Lady Ann' and 'Lady Beth', respectively). 'Red Hot' and 'Southern Blush' exhibited the next highest genetic similarity with $\mathrm{C}$ and $\mathrm{d}$ values of 0.89 and 0.33 , respectively. Henny et al. (1988) reported that these two cultivars, 'Red Hot' [(A. andraeanum $\times$ A. amnicola) $\times$ A. 'Lady Jane'] and 'Southern Blush' (A. andraeanum $\times$ A. amnicola) share common parents. Our results in this study confirm their common pedigree. A high degree of genetic similarity was also apparent between 'Lollipop' and 'Pink Aristocrat' based on the $\mathrm{C}(0.84)$ and $\mathrm{d}(0.38)$ values. The parentage for these two cultivars is unknown. In contrast, 'Southern Blush' and 'Red Hot' appear to be more distantly related to the other cultivars based on relatively high d values between these two and other cultivars.

The RAPD results obtained in this study provide an adequate number of DFP patterns to identify each Anthurium cultivar. Primers $\mathrm{B}_{20}$ and $\mathrm{AJ}_{2}$ generated a high number of DFPs
Table 1. Summary of DFP profiles and polymorphisms obtained for nine Anthurium cultivars by random primers. Only reproducible RAPD bands were scored. Single bands are the unique bands specific for a cultivar.

\begin{tabular}{lccccc}
\hline \hline $\begin{array}{l}\text { Primer } \\
\text { no. }\end{array}$ & $\begin{array}{c}\text { Primer sequence } \\
\left(5^{\prime} \text { to }{ }^{\prime}\right)\end{array}$ & \multicolumn{3}{c}{ No. of bands } & \begin{tabular}{c} 
No. of \\
\cline { 3 - 4 } DFP profiles $^{2}$
\end{tabular} \\
\hline B1 & GTTTCGCTCC & 10 & 5 & 3 & 5 \\
B2 & TGATCCCTGG & 8 & 5 & --- & 7 \\
B10 & CTGCTGGGAC & 12 & 8 & 1 & 7 \\
B13 & TTCCCCCGCT & 12 & 8 & 1 & 8 \\
B18 & CCACAGCAGT & 16 & 13 & --- & 8 \\
B20 & GGACCCTTAC & 13 & 10 & --- & 9 \\
AJ2 & TCGCACAGTC & 15 & 12 & --- & 9 \\
AK4 & AGGGTCGGTC & 9 & 5 & -- & 6 \\
AK15 & ACCTGCCGTT & 9 & 8 & 1 & 8 \\
Total & & 104 & 74 & 6 & \\
\hline
\end{tabular}

${ }^{2}$ No. of DFP profiles are based on specific banding patterns.

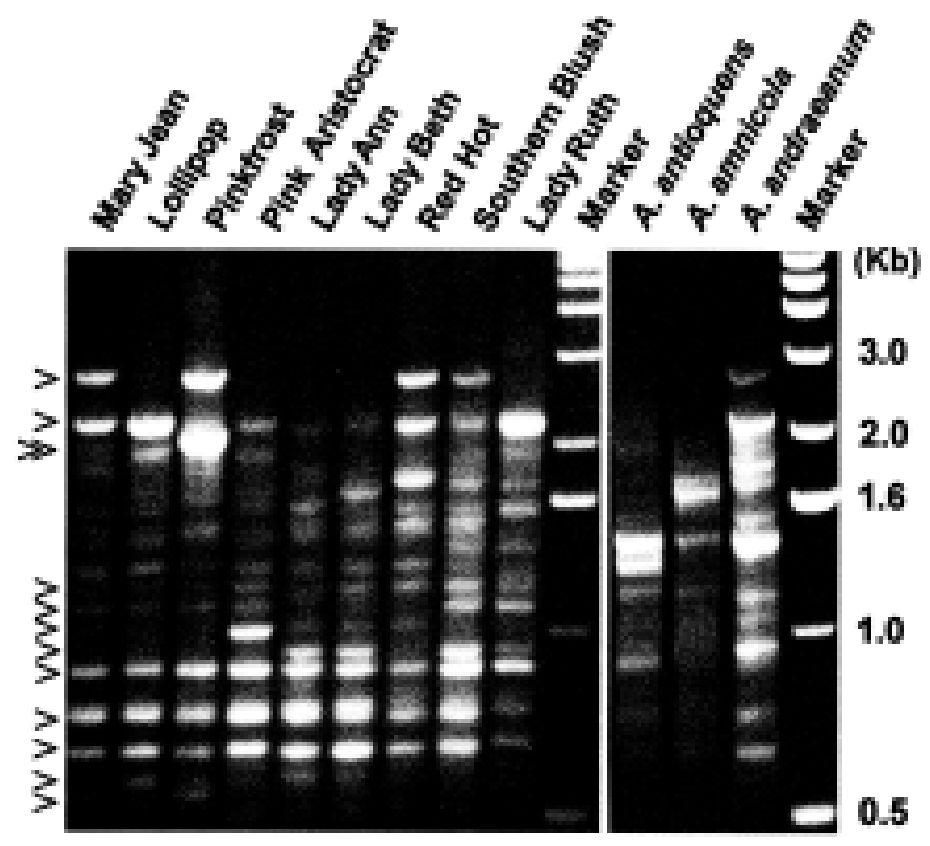

Fig. 1. RAPD amplification profiles generated by arbitrary primer OPB10 for nine Anthurium cultivars. Closely related cultivars exhibit more similar DNA fingerprints. > Indicates reproducible, easily counted bands that were scored. Of the three species, a higher percentage of bands was shared by $A$. andraeanum. $\gg$ Indicates a single band present only in the cultivar 'Pinkfrost' and not shared by any of the three species.

Table 2. Coefficient of similarity (C) and genetic distance (d) values among nine Anthurium cultivars, based on RAPDs. $\mathrm{C}$ values are to the right and $\mathrm{d}$ values to the left of the diagonal.

\begin{tabular}{|c|c|c|c|c|c|c|c|c|c|}
\hline \multirow[b]{2}{*}{ Cultivar } & \multicolumn{9}{|c|}{ Cultivar } \\
\hline & $\begin{array}{l}\text { Mary } \\
\text { Jean }\end{array}$ & Lollipop & $\begin{array}{l}\text { Pink } \\
\text { Frost }\end{array}$ & $\begin{array}{c}\text { Pink } \\
\text { Aristocrat }\end{array}$ & $\begin{array}{l}\text { Lady } \\
\text { Ann }\end{array}$ & $\begin{array}{l}\text { Lady } \\
\text { Beth }\end{array}$ & $\begin{array}{l}\text { Lady } \\
\text { Ruth }\end{array}$ & $\begin{array}{l}\text { Red } \\
\text { Hot }\end{array}$ & $\begin{array}{c}\text { Southern } \\
\text { Blush }\end{array}$ \\
\hline Mary Jean & --- & 0.79 & 0.81 & 0.76 & 0.79 & 0.82 & 0.74 & 0.74 & 0.74 \\
\hline Lollipop & 0.50 & --- & 0.80 & 0.84 & 0.74 & 0.78 & 0.75 & 0.80 & 0.78 \\
\hline Pink Frost & 0.46 & 0.47 & --- & 0.71 & 0.72 & 0.75 & 0.71 & 0.74 & 0.70 \\
\hline Pink Aristocrat & 0.58 & 0.39 & 0.64 & --- & 0.70 & 0.71 & 0.69 & 0.78 & 0.82 \\
\hline Lady Ann & 0.48 & 0.50 & 0.55 & 0.63 & --- & 0.98 & 0.79 & 0.72 & 0.71 \\
\hline Lady Beth & 0.44 & 0.49 & 0.57 & 0.62 & 0.06 & --- & 0.80 & 0.73 & 0.72 \\
\hline Lady Ruth & 0.53 & 0.50 & 0.58 & 0.57 & 0.43 & 0.41 & --- & 0.68 & 0.71 \\
\hline Red Hot & 0.58 & 0.51 & 0.65 & 0.46 & 0.63 & 0.62 & 0.64 & --- & 0.89 \\
\hline Southern Blush & 0.65 & 0.60 & 0.69 & 0.53 & 0.64 & 0.66 & 0.59 & 0.33 & --- \\
\hline
\end{tabular}


Table 3. RAPD band sharing by cultivars and three parent species of Anthurium. Bands were generated using nine primers. ${ }^{\mathrm{z}}$

\begin{tabular}{|c|c|c|c|c|c|c|}
\hline \multirow[b]{2}{*}{ Cultivar } & \multicolumn{2}{|c|}{ A. andraeanum } & \multicolumn{2}{|c|}{ A. antioquens } & \multicolumn{2}{|c|}{ A. amnicola } \\
\hline & No. & $(\%)$ & No. & $(\%)$ & No. & $(\%)$ \\
\hline Mary Jean & 35 & 33.7 & 27 & 26.0 & 15 & 14.4 \\
\hline Lollipop & 43 & 41.4 & 15 & 14.4 & 27 & 26.0 \\
\hline Pink Frost & 42 & 40.4 & 18 & 17.3 & 12 & 11.5 \\
\hline Pink Aristocrat & 46 & 44.2 & 18 & 17.3 & 23 & 22.1 \\
\hline Lady Ann & 52 & 50.0 & 35 & 33.7 & 10 & 9.6 \\
\hline Lady Beth & 50 & 48.1 & 41 & 39.4 & 7 & 6.7 \\
\hline Lady Ruth & 32 & 30.8 & 15 & 14.4 & 17 & 16.3 \\
\hline Red Hot & 58 & 55.8 & 8 & 7.7 & 33 & 31.7 \\
\hline Southern Blush & 45 & 43.3 & 12 & 11.5 & 29 & 27.9 \\
\hline Total & 403 & 43.1 & 189 & 20.2 & 143 & 15.3 \\
\hline
\end{tabular}

${ }^{\mathrm{z}}$ Since each cultivar had 104 bands when data for all nine primers were pooled, percentage of sharing of bands by each species was calculated as a fraction of 104 .

with unique fingerprints for every cultivar. Thus, these primers could be utilized to identify very similar cultivars, such as 'Lady Ann' and 'Lady Beth'.

Band sharing with parent species. Results indicated a number of species-specific bands. However, some RAPD bands present in cultivars were not shared by any of the three species tested (Fig. 1). In contrast, a few bands were shared by more than one species. Bands shared by different species may have different origins (Karp et al., 1996; Skepner and Krane, 1998). Of 104 reproducible bands used in this study, A. andraeanum shared a greater percentage $(43.1 \%)$ with each of the nine cultivars than did either $A$. antioquence $(20.2 \%)$ or A. amnicola (15.3\%) (Table 3). Bands of 'Lady Ann' or 'Lady Beth' were mostly shared by $A$. andraeanum and $A$. antioquence, while bands present in 'Red Hot' and 'Southern Blush' were largely shared by $A$. andraeanum and $A$. amnicola (Table 3 ). In each case, these results are consistent with the known parents of the four hybrids. However, we were unable to make inferences as to the species involved in the parentage of unknown cultivars.

The main objectives of this study were to generate DNA fingerprint patterns to: 1) distinguish between nine different pot plant Anthurium cultivars; and 2) determine the genetic relationship among them. Identifying the parental species of each cultivar using RAPD was beyond the scope of this study. As discussed before, only four of the nine cultivars used in this study have a known pedigree. However, closely related cultivars with known parents generated uniform RAPD patterns and these results may provide some insight into understanding the relationships among cultivars with undocumented lineages. Cultivar comparisons, such as 'Pink Aristocrat' vs. 'Southern Blush', 'Mary Jean' vs. 'Lady Beth', and 'Pink Aristocrat' vs. 'Lollipop', exhibit close genetic relationships, probably indicating common parents; however, this needs to be verified. Although the parentage of several commercial cultivars developed by private industry is proprietary, many morphological similarities between cultivars exist and point to a common genetic background. In this study, relatively high $\mathrm{C}$ values and low $\mathrm{d}$ values among all cultivars support this view. Thus, future Anthurium breeding programs should consider incorporating other species from the highly diversi- fied pool of this genus to broaden the genetic base of commercial pot plant cultivars.

\section{Literature Cited}

Armstrong,J.S., A.J.Gibbs, R.Peakall, and G. Weiller. 1994. RAPDistance Programs; Version 1.03 for the analysis of patterns of RAPD fragments. Res. School of Biological Sci., Australian Natl. Univ., P.O. Box 4, Canberra, ACT 2601, Australia. http://life.anu.edu.au/molecular/software/ rapd.html.

Henny, R.J., R.T. Poole, and C.A. Conover. 1988. 'Southern Blush' Anthurium. HortScience 23:922-923.

Kamemoto, H. 1981. Anthurium breeding in Hawaii. Aroideana 4:77-85.

Kamemoto, H. and R.D. Sheffer. 1978. A new species hybrid, Anthurium scherzerianum $\times$ Anthurium wendlingerii. HortScience 13:177-179.

Karp A., O. Seberg, and M. Buiatti. 1996. Molecular techniques in the assessment of botanical diversity. Ann. Bot. 78:143-149.

Kobayashi, R.S., J.L. Brewbaker, and H. Kamemoto. 1987. Identification of Anthurium andraeanum cultivars by gel electrophoresis. J. Amer. Soc. Hort. Sci. 112:164-167.

Mullis, K., F. Faloona, S. Scharf, R. Saiki, G. Horn, and H. Erlich. 1986. Specific enzymatic amplification of DNA in vitro: The polymerase chain reaction. Cold Spring Harb. Symp. Quant. Biol. 51:263-273.

Nei, M. and W. Li. 1979. Mathematical model for studying genetic variation in terms of restriction endonucleases. Proc. Natl. Acad. Sci. USA 76:5269-5273.

Sambrook, J., E.F. Fritsch, and T. Maniatis. 1989. Molecular cloning. A laboratory manual, 2nd ed. Cold Spring Harbor Lab. Press, Cold Spring Harbor, N.Y.

Skepner, A.P. and D.E. Krane. 1998. RAPD reveals genetic similarity of Acer saccharum and Acer nigrum. Heredity 80:422-428.

Sneath, P.H.A. and R.R. Sokal. 1973. Numerical taxonomy. Freeman, San Francisco.

Williams, J.G.K., M.K. Hanafey, J.A. Rafalski, and S.V. Tingey. 1993. Genetic analysis using random amplified polymorphic DNA markers. Methods in Enzymol. 318:704-741. 